\title{
Regulatory responses to excess zinc ingestion in growing rats
}

\author{
Tomoya Fujimura, Tohru Matsui and Masayuki Funaba* \\ Division of Applied Biosciences, Graduate School of Agriculture, Kyoto University, Kitashirakawa Oiwakecho, \\ Kyoto 606-8502, Japan \\ (Submitted 14 April 2011 - Final revision received 27 July 2011 - Accepted 31 July 2011 - First published online 12 September 2011)
}

\section{Abstract}

The growth of weaning piglets is effectively improved by feeding a high- $\mathrm{Zn}$ diet $(3000 \mathrm{mg} \mathrm{Zn} / \mathrm{kg}$ of diet). The present study examined whether feeding a diet supplemented with $\mathrm{Zn}(1016-3000 \mathrm{mg} / \mathrm{kg})$ for $10 \mathrm{~d}$ induces growth benefits in rats. In addition, tissue weight, $\mathrm{Zn}$ content of tissues and expression of $\mathrm{Zn}$ transporters were examined in these rats. Zn supplementation did not significantly increase body weight. Breaking line model analyses indicated that the weight of the pancreas, the organ most sensitive to excess $\mathrm{Zn}$, significantly decreased with increasing $\mathrm{Zn}$ intake beyond $15 \cdot 2 \mathrm{mg} / \mathrm{d}$. Excess $\mathrm{Zn}$ has been suggested to accumulate in the liver, kidney and bone in order to protect the pancreas. Zn concentrations in the plasma, liver, kidney and femur increased with increasing Zn intake up to approximately $30 \mathrm{mg} / \mathrm{d}$, whereas those in the pancreas increased up to $8.4 \mathrm{mg} / \mathrm{d}$ and decreased by Zn intake beyond $8.4 \mathrm{mg} / \mathrm{d}$. The expression levels of the $Z n$ transporters $Z i p 4$ and $Z n T 1$ in the intestinal epithelium were significantly lower in rats fed a diet supplemented with $1016 \mathrm{mg} / \mathrm{kg}$ $\mathrm{Zn}$ compared to those fed the basal diet. The present study reveals that (1) excess Zn intake does not accelerate growth in rats, but is detrimental to the pancreas, (2) the excess $\mathrm{Zn}$ is effectively accumulated in the liver, kidney and bone, without sufficient protection of the pancreas and (3) expression of $\mathrm{Zn}$ transporters is down-regulated in response to excess $\mathrm{Zn}$ intake.

\section{Key words: Excess zinc: Zinc accumulation: Zinc transporters: Growth}

$\mathrm{Zn}$ is an essential mineral that acts as a cofactor for numerous enzymes and transcription factors ${ }^{(1)}$. The physiological responses to $\mathrm{Zn}$ deficiency are well-characterised in mammals ${ }^{(2-5)}$, whereas less information is available regarding the effects of excess $\mathrm{Zn}$ intake. The pancreas has been suggested as the tissue most sensitive to excess $\mathrm{Zn}^{(6)}$. The National Research Council (NRC) ${ }^{(7)}$ proposes that $\mathrm{Zn}$ accumulates in tissues such as the liver, kidney and bone, in order to protect other organs from failure induced by $\mathrm{Zn}$ accumulation. $\mathrm{Zn}$ concentrations were increased in the liver (6-fold) and in the kidney (11-fold) in preruminant calves fed a diet supplemented with 500-700 mg Zn/kg, whereas the increases in $\mathrm{Zn}$ concentration in the heart and muscle were relatively smaller ${ }^{(8)}$; similar results were obtained in sheep fed a diet supplemented with 700-2100 $\mathrm{mg} \mathrm{Zn} / \mathrm{kg}^{(9)}$. Furthermore, $\mathrm{Zn}$ concentrations in the liver, kidney and bone were higher in rats fed a diet supplemented with $2438 \mathrm{mg} \mathrm{Zn/kg} \mathrm{compared}$ with growing rats fed a diet containing $38 \mathrm{mg} \mathrm{Zn} / \mathrm{kg}$, and the $\mathrm{Zn}$ concentration of these tissues plateaued at supplementation levels of $2438-7238 \mathrm{mg} \mathrm{Zn/} \mathrm{kg}^{(10)}$.

Elevated $\mathrm{Zn}$ intake $(3000 \mathrm{mg} / \mathrm{kg}$ ) for a period of $14 \mathrm{~d}$ surprisingly induces growth in weaning piglets ${ }^{(11-13)}$. Considering that the $\mathrm{Zn}$ requirement for growing pigs is $100 \mathrm{mg} / \mathrm{kg}^{(14)}$, the $\mathrm{Zn}$-induced growth promotion results from the pharmacological effects of excess $\mathrm{Zn}$ intake. The physiological basis for these pharmacological effects remains unclear. $\mathrm{ZnO}$ possesses antimicrobial properties ${ }^{(15)}$, but several studies suggest that $\mathrm{ZnO}$ promotes growth in early-weaned and conventionally weaned pigs, regardless of diarrhoea prevalence or intestinal microbial numbers ${ }^{(16-18)}$.

Zn homeostasis is primarily maintained by regulation of its absorption and secretion. Several $\mathrm{Zn}$ transporters of the Slc39 (Zip) and Slc30 (ZnT) families have been identified. Members of the Zip family have been shown to increase the cytosolic Zn concentration, whereas those of the ZnT family decrease the cytosolic concentration ${ }^{(19-22)}$. Zip4 and ZnT1 are involved in $\mathrm{Zn}$ absorption in the small intestine ${ }^{(23,24)}$, whereas Zip5 is responsible for intestinal $\mathrm{Zn}$ secretion ${ }^{(25)}$. In addition, $\mathrm{Zn}$ is secreted from the pancreas into the gut by Zip5 and $Z n T 1^{(25,26)}$. Zn transporter activities are modulated in response to $\mathrm{Zn}$ depletion through alteration of gene expression, transporter translocation, or both ${ }^{(22)}$

We hypothesised that growth promotion induced by excess $\mathrm{Zn}$ intake $(3000 \mathrm{mg} / \mathrm{kg}$ ) is not limited to weaning piglets but is instead observed in other animals, including rats. In addition, it was hypothesised that each tissue grows proportionally in

Abbreviations: BW, body weight; Hprt1, hypoxanthine phosphoribosyltransferase 1 ; Igf-1, insulin-like growth factor-1; $M t$, metallothionein; NRC, National Research Council.

*Corresponding author: M. Funaba, fax +81 75753 6344, email mfunaba@kais.kyoto-u.ac.jp 
rats fed diets supplemented with excess $\mathrm{Zn}$. In order to examine these points, we examined body and tissue growth, accumulation of $\mathrm{Zn}$ in tissues and expression of $\mathrm{Zn}$ transporters in growing rats fed diets supplemented with excess $\mathrm{Zn}$. We specifically examined (1) whether growth promotion induced by excess $\mathrm{Zn}$ is observed in growing rats, (2) whether the concept proposed by the NRC regarding the prevention from $\mathrm{Zn}$ toxicity is applicable and (3) whether $\mathrm{Zn}$ transporter gene expression is altered in response to excess $\mathrm{Zn}$ ingestion. Our results indicate that excess $\mathrm{Zn}$ ingestion did not enhance the growth performance in growing rats, but in fact decreased pancreatic weight. Unexpectedly, the gene transcript levels of both the intestinal $\mathrm{Zn}$ transporters involved in $\mathrm{Zn}$ absorption and those involved in secretion were decreased in rats fed diets with higher $\mathrm{Zn}$ contents.

\section{Materials and methods}

\section{Animals and diets}

The experiments were approved by the Kyoto University Animal Experiment Committee (20-19). A total of twentyeight male specific pathogen-free Sprague-Dawley rats aged 4 weeks were housed individually in stainless-steel cages under constant conditions $\left(24^{\circ} \mathrm{C}, 50 \%\right.$ humidity) with a fixed light-dark cycle (lights on from 05.00 to 19.00 hours). Because excess $\mathrm{Zn}$-induced growth promotion in weaning pigs is not necessarily due to the antimicrobial effects as described earlier, we used specific pathogen-free rats. After a $5 \mathrm{~d}$ acclimatisation period of feeding the basal diet $(24 \mathrm{mg} \mathrm{Zn} / \mathrm{kg}$ ) shown in Table 1 , rats were randomly assigned to receive diets with differing $\mathrm{Zn}$ concentrations. The requirement of $\mathrm{Zn}$ in growing rats is $12 \mathrm{mg} / \mathrm{kg}^{(27)}$; the basal diet contained twice as much $\mathrm{Zn}^{(27)}$. $\mathrm{Zn}$ content in the diet recommended

Table 1. Ingredients of the basal diet

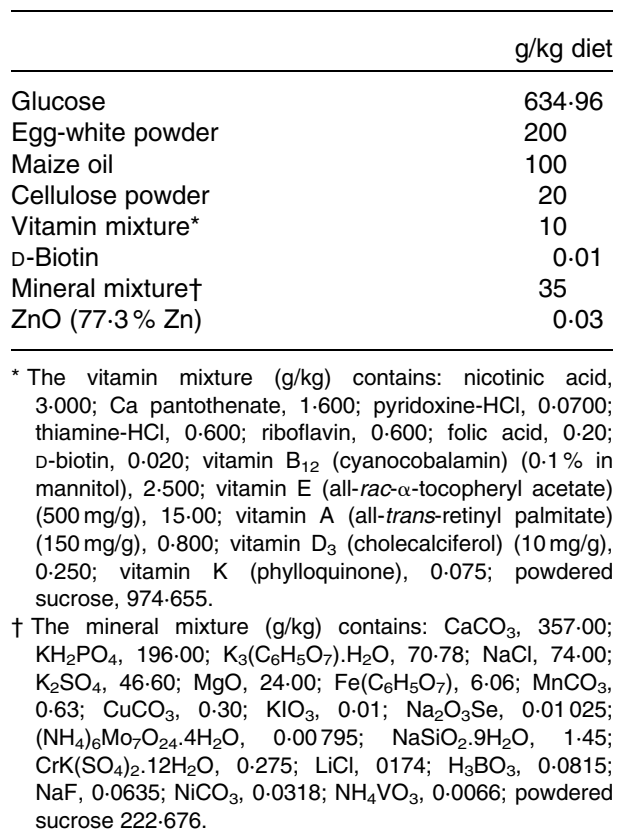

for growing rats by $\mathrm{AIN}^{(28)}$ is $30 \mathrm{mg} / \mathrm{kg}$. All groups were allowed free access to food and distilled water for the $10 \mathrm{~d}$ study period. The diets were prepared by addition of $\mathrm{ZnO}$ to a $\mathrm{Zn}$-deficient diet at the expense of glucose to provide a 24, 1016, 2008 or $3000 \mathrm{mg} \mathrm{Zn/kg} \mathrm{diet,} \mathrm{and} \mathrm{the} \mathrm{actual} \mathrm{measured}$ content was $23 \cdot 8,1050,2090$ or $3200 \mathrm{mg} \mathrm{Zn/kg} \mathrm{diet,} \mathrm{respect-}$ ively. Since this study tested responses to dietary $\mathrm{Zn}$ status, i.e. excess intake as well as deficiency, egg-white was used as a protein source. D-Biotin was added to the basal diet due to the high avidin content of egg-white in order to prevent biotin deficiency. Body weight (BW) and feed consumption were measured every day.

At the end of the $10 \mathrm{~d}$ experimental period, rats were killed by bleeding from the abdominal aorta under isoflurane anaesthesia. Tissues (the liver, kidney, pancreas, spleen, small intestine, testis, gastrocnemius muscle, femur and perirenal fat pad) were collected and weighed. Blood collected with a heparinised syringe was centrifuged at $2500 \boldsymbol{g}$ for $30 \mathrm{~min}$ at $4^{\circ} \mathrm{C}$ to obtain the plasma. The intestine was flushed with saline and scraped with slide glass to obtain the intestinal epithelium. Other tissues were rinsed in saline, immediately frozen in liquid $\mathrm{N}_{2}$ and stored at $-80^{\circ} \mathrm{C}$ until analysis.

\section{Determination of mineral contents}

After wet-ash digestion of diets, plasma, and tissues with traceelement grade nitric acid and $\mathrm{H}_{2} \mathrm{O}_{2}, \mathrm{Zn}$ concentrations in diets, plasma and tissues were measured by atomic absorption spectrometry (AA-6600F; Shimadzu, Kyoto, Japan). The analytical accuracy of the $\mathrm{Zn}$ determination was confirmed by analysis of a certified reference material from bovine liver (standard reference material $1577 \mathrm{~b}$, National Institute of Standards and Technology, Gaithersburg, MD, USA).

\section{RNA extraction and quantitative $R T-P C R$}

Total RNA was isolated from the small intestine epithelium, pancreas and liver using TRIzol reagent (Invitrogen, Carlsbad, CA, USA), according to the manufacturer's protocol. Recovered RNA was used as a template for RT using random primers (ABI high-capacity complementary DNA reverse transcription kit; Applied Biosystems, Foster City, CA, USA). The quantitative RT-PCR was carried out using an SYBR premix Ex Taq II kit (TaKaRa, Otsu, Japan) in a Roter-Gene 6000 instrument (Corbett Research, Mortlake, Australia). PCR was performed as follows: an initial denaturation step of $10 \mathrm{~s}$ at $95^{\circ} \mathrm{C}$, followed by forty cycles of $5 \mathrm{~s}$ at $95^{\circ} \mathrm{C}$ and $20 \mathrm{~s}$ at $60^{\circ} \mathrm{C}$. The dissociation (melting) curve of quantitative RT-PCR products was subsequently examined by changing the ramp temperature from $60^{\circ} \mathrm{C}$ to $94^{\circ} \mathrm{C}$. Each sample showed a single peak, suggesting that the expected PCR products were obtained. The PCR primers used to detect Zip4, Zip5, ZnT1, metallothionein-1a $(M t-1 a), M t-2 a$, insulin-like growth factor-1 (Igf-1) and hypoxanthine phosphoribosyltransferase 1 (Hprt1) were as follows: $5^{\prime}$-AAC CCA CCA GGG AGG AGA- $3^{\prime}$ and $5^{\prime}$-TTC TGG AAA CCC CTG CTT $\mathrm{C}^{\prime}-3^{\prime}$ for Zip4; 5'-CCT CGG GCC TAG ACC TCT $\mathrm{T}-3^{\prime}$ and $5^{\prime}$-AGC TGG GAA CCA TTC AGA CA- $3^{\prime}$ for Zip5; 5'-AAC ACC AGC AAT TCC AAC G-3' and 5'-CCA CTG 


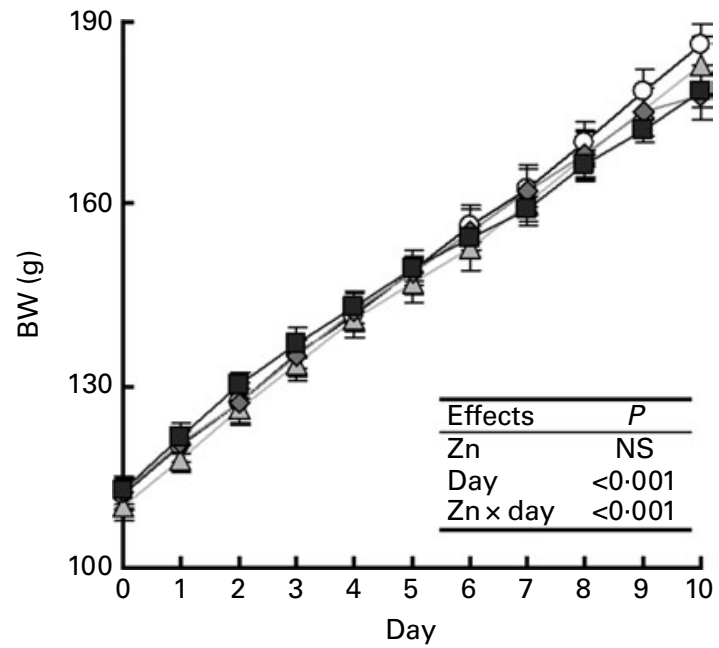

Fig. 1. Time-course changes in body weight (BW) in growing rats. Rats were fed diets containing various concentrations of $\mathrm{Zn}$ for $10 \mathrm{~d}$. BW was plotted against experimental days. Values are means with their standard errors represented by vertical bars $(n 7)$. $-0-, 24 \mathrm{mg} \mathrm{Zn/kg;}-\downarrow, 1016 \mathrm{mg} \mathrm{Zn/kg;} \prec$, $2008 \mathrm{mg} \mathrm{Zn/kg;}-$ - $3000 \mathrm{mg} \mathrm{Zn/kg}$.

GAT CAT CAC TTC TCA A- $3^{\prime}$ for ZnT1; 5'-CAC CAG ATC TCG GAA TGG AC- $3^{\prime}$ and $5^{\prime}$-GCA GCA GCT CTT CTT GCA G- $3^{\prime}$ for $M t-1 a ; 5^{\prime}$-ACC TCC TGC AAG AAA AGC TG- $3^{\prime}$ and $5^{\prime}$-ACT TGT CCG AAG CCT CTT TG-3' for $M t-2 a ; 5^{\prime}$-GGA CGC TCT TCA ATT CGT GT-3' and 5'-CTT CAG CGG AGC ACA GTA CA- $3^{\prime}$ for $I g f-1$; and $5^{\prime}$-GAC CGG TTC TGT CAT GTC G-3' and $5^{\prime}$-ACC TGG TTC ATC ATC ACT AAT CAC-3' for Hprt1. Gene transcript levels in each sample were determined using the relative standard curve method. The level of gene transcripts was expressed as a ratio relative to Hprt1 mRNA, with the level in rats fed the basal diet set to 1 .

\section{Statistical analyses}

Data are expressed as the least square means with their standard errors. All analyses were performed using SAS (SAS Institute, Cary, NC, USA) ${ }^{(29)}$. The data on BW and feed intake were subjected to the MIXED procedure. Each rat was determined an experimental unit and measurements of the same rat on different days were considered repeated measures. The statistical model included the effects of diet, experimental day and the interaction between both. In addition, the effects of dietary $\mathrm{Zn}$ on tissue weight were analysed with the general linear model procedure. Furthermore, when tissue $\mathrm{Zn}$ concentrations or weights were plotted against daily $\mathrm{Zn}$ intake, a breaking point of daily $\mathrm{Zn}$ intake indicating a plateau was explored using the NLIN procedure. A model with 1 breaking point and no limit of its slope value before or after the point was applied. When the model was significant, and when the slope was not significantly different from 0 , the breaking point was further determined by application of the model with 1 breaking point with 0 as the slope after the point. Differences were considered significant at $P<0.05$.

\section{Results}

\section{Body and tissue growth}

Time-course changes in BW showed an insignificant effect of diet, but the effect of the interaction between diet and experimental day was significant, suggesting that the effect of excess $\mathrm{Zn}$ on BW depended on the length of the treatment period (Fig. 1). This indicates that, unlike in piglets, a diet supplemented with $3000 \mathrm{mg} \mathrm{Zn} / \mathrm{kg}$ does not have a beneficial effect on BW gain in rats. As for daily feed intake, both the diet effect and the interaction between diet and experimental day were not statistically significant (Fig. 2(A)). In addition, feed efficiency, i.e. weight gain per feed intake, was not significantly affected by the diet, the experimental day or the interaction between both (Fig. 2(B)) .

Typical symptoms of Zn toxicity are vomiting and gastrointestinal dysfunction ${ }^{(30)}$, and the pancreas is the organ most sensitive to $\mathrm{Zn}$ toxicity ${ }^{(6)}$. Two rats fed a diet supplemented with $3000 \mathrm{mg} \mathrm{Zn/kg}$ excreted soft stools for the last $3 \mathrm{~d}$ of the experimental period, although the other rats did not exhibit any symptoms throughout the study. The weight of the pancreas relative to $\mathrm{BW}$ was lower in rats fed a diet
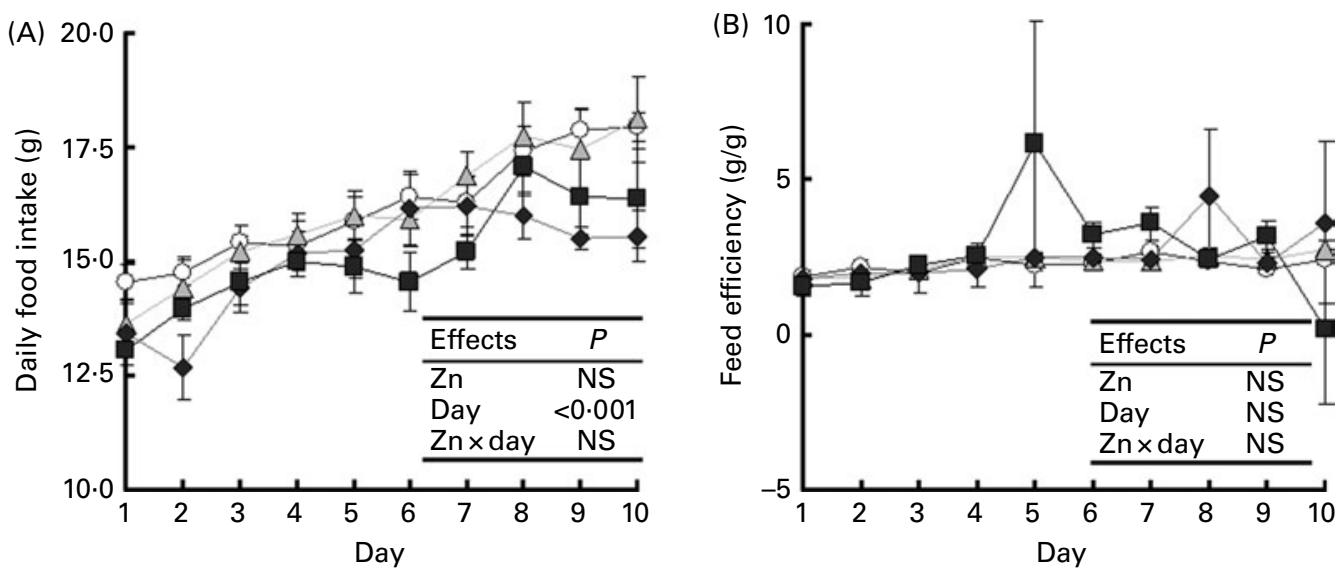

Fig. 2. Time-course changes in daily feed intake and feed efficiency in growing rats. Rats were fed diets containing various concentrations of Zn for $10 \mathrm{~d}$ (A) Daily feed intake and (B) feed efficiency were plotted against experimental days. Values are means with their standard errors represented by vertical bars (n 7). -O-, $24 \mathrm{mg} \mathrm{Zn/kg;}-$, $1016 \mathrm{mg} \mathrm{Zn/kg;} \mathrm{\multimap -,} 2008 \mathrm{mg} \mathrm{Zn/kg;} \mathrm{\multimap -,} 3000 \mathrm{mg} \mathrm{Zn/kg}$. 
Table 2. Relative tissue weight of rats fed the diets supplemented with excess zinc (Mean values with their standard errors, $n 7$ )

\begin{tabular}{|c|c|c|c|c|c|c|}
\hline Dietary Zn (mg/kg diet)... & 24 & 1016 & 2008 & 3000 & SEM & $P$ \\
\hline \multicolumn{7}{|l|}{ Tissue weight (mg/g BW) } \\
\hline Liver & $45 \cdot 9$ & $45 \cdot 0$ & $47 \cdot 8$ & 48.5 & 1.4 & NS \\
\hline Kidney* & 4.57 & 4.51 & 4.86 & 4.77 & 0.15 & NS \\
\hline Pancreas & $6 \cdot 19^{a}$ & $6.57^{\mathrm{a}}$ & $5 \cdot 18^{\mathrm{b}}$ & $5 \cdot 19^{b}$ & 0.28 & $<0.003$ \\
\hline Spleen & 2.51 & 2.47 & 2.42 & $2 \cdot 80$ & $0 \cdot 10$ & NS \\
\hline Testis* & $5 \cdot 16$ & $5 \cdot 30$ & 5.56 & 5.42 & 0.23 & NS \\
\hline Gastrocnemius muscle* & 0.98 & 0.96 & 0.95 & 0.90 & 0.04 & NS \\
\hline Femur ${ }^{\star}$ & 3.81 & 3.75 & 3.99 & 3.74 & 0.09 & NS \\
\hline Perirenal fat ${ }^{\star}$ & 4.93 & 4.24 & 3.50 & 3.43 & 0.51 & NS \\
\hline
\end{tabular}

${ }^{\mathrm{a}, \mathrm{b}}$ Mean values with unlike letters were significantly different $(P<0.05)$.

* Average weight of tissues from both left and right parts.

supplemented with $2008 \mathrm{mg} \mathrm{Zn} / \mathrm{kg}$ or $3000 \mathrm{mg} \mathrm{Zn/kg} \mathrm{com-}$ pared to those fed a diet supplemented with $24 \mathrm{mg} \mathrm{Zn} / \mathrm{kg}$ or $1016 \mathrm{mg} \mathrm{Zn} / \mathrm{kg}$, whereas no significant effects of the diet on the weight of the liver, kidney, spleen, testis, gastrocnemius muscle, femur and perirenal fat were detected (Table 2). Plotting the pancreas weight against daily $\mathrm{Zn}$ intake revealed a decrease in rats that ingested $\mathrm{Zn}$ at levels above $15.2 \mathrm{mg} / \mathrm{d}$ (Fig. 3).

\section{Plasma and tissue zinc concentration}

Plasma and tissue $\mathrm{Zn}$ concentrations were higher in rats fed diets supplemented with more than $1016 \mathrm{mg} \mathrm{Zn} / \mathrm{kg}$ than in those fed the basal diet (data not shown). To examine the relationship between $\mathrm{Zn}$ intake and the $\mathrm{Zn}$ concentrations in detail, plasma and tissue $\mathrm{Zn}$ concentrations were plotted against daily $\mathrm{Zn}$ intake (Fig. 4). Zn concentrations in the plasma, liver, kidney and femur increased linearly with increasing intake of $\mathrm{Zn}$ up to $31 \cdot 3,37 \cdot 1,28 \cdot 3$ and $35 \cdot 1 \mathrm{mg} / \mathrm{d}$, respectively, and eventually reached a plateau (Fig. 4(A)-(D)). These results suggest that $\mathrm{Zn}$ efficiently accumulates in the plasma, liver, kidney and femur in response to increased $\mathrm{Zn}$ intake and that the capacity to retain $\mathrm{Zn}$ is limited. In view of the higher proportion of skeletal muscle weight relative to total BW, approximately $60 \%$ of body $\mathrm{Zn}$ is stored in the muscle tissue ${ }^{(31)}$; however, the $\mathrm{Zn}$ concentration in the muscle was not significantly altered by increasing $\mathrm{Zn}$ intake (Fig. 4(E)).

The relationship between the $\mathrm{Zn}$ concentration in the pancreas and daily $\mathrm{Zn}$ intake also indicated that the breaking point was $8.4 \mathrm{mg} / \mathrm{d}$; the pancreatic $Z n$ concentration increased up to this point (Fig. 4(F)). In contrast to the plasma, liver, kidney and femur, the $\mathrm{Zn}$ concentration in the pancreas linearly decreased in rats that ingested $\mathrm{Zn}$ above the breaking point.

\section{Expression of zinc transporters, metallothionein and insulin-like growth factor-1}

The gene transcript levels of the transporters involved in intestinal absorption and secretion of $\mathrm{Zn}$ were examined by quantitative RT-PCR (Fig. 5). Expression of Zip4 in the intestinal epithelium, which is responsible for the uptake of $\mathrm{Zn}$ across the mucosal membrane ${ }^{(24)}$, was significantly lower in rats fed a diet supplemented with $1016 \mathrm{mg} \mathrm{Zn/kg}$ than in those fed the basal diet, with no differences among dietary groups with higher Zn contents (Fig. 5(A)). The expression of ZnT1 in the intestinal epithelium, which promotes $\mathrm{Zn}$ transport from the cytosol of epithelial cells to the portal vein ${ }^{(23)}$, was also down-regulated in rats fed diets supplemented with 1016-3000 mg Zn/kg (Fig. 5(B)). Zip5 is located at the basolateral membrane of the intestinal epithelium and promotes $\mathrm{Zn}$ transport from the portal vein to epithelial cells ${ }^{(25)}$. The expression of Zip5 was down-regulated in rats fed diets supplemented with $1016-3000 \mathrm{mg} \mathrm{Zn} / \mathrm{kg}$; the expression in rats fed a diet supplemented with $2008 \mathrm{mg} \mathrm{Zn} / \mathrm{kg}$ was higher than that in rats fed a diet containing $1016 \mathrm{mg} \mathrm{Zn} / \mathrm{kg}$ (Fig. 5(C)). No significant differences were detected in the expression of ZnT1 and Zip5, transporters responsible for $\mathrm{Zn}$ secretion into the gut ${ }^{(25,26)}$, in the pancreas (Fig. 5(D) and (E)).

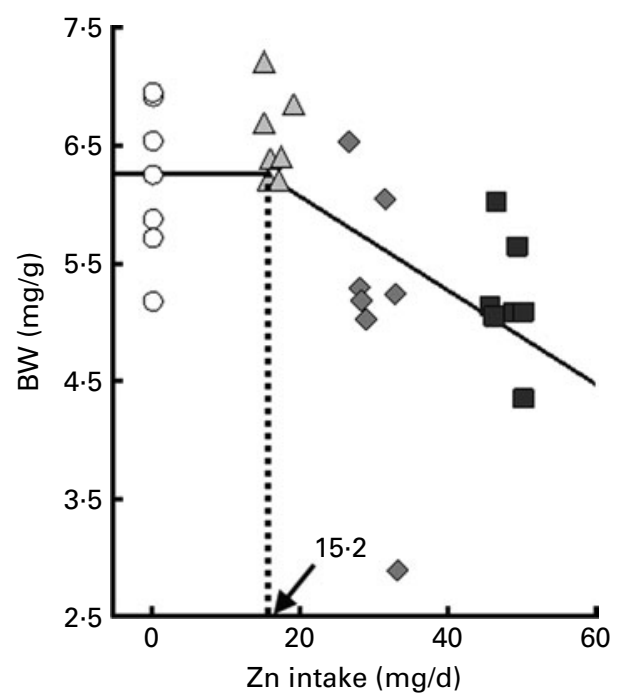

Fig. 3. Effects of excess $\mathrm{Zn}$ intake on the weight of the pancreas in growing rats. Rats were fed diets with various concentrations of $\mathrm{Zn}$ for $10 \mathrm{~d}$. The weight of the pancreas relative to body weight (BW) was plotted against average daily intake of $\mathrm{Zn}$. The breaking point of daily $\mathrm{Zn}$ intake on the pancreas weight was calculated, and shown in the figure by an arrow. O, $24 \mathrm{mg}$ $\mathrm{Zn} / \mathrm{kg} ; \triangle, 1016 \mathrm{mg} \mathrm{Zn/kg;} \mathrm{\diamond ,} 2008 \mathrm{mg} \mathrm{Zn/kg;} \mathrm{\square ,} 3000 \mathrm{mg} \mathrm{Zn/kg}$. 

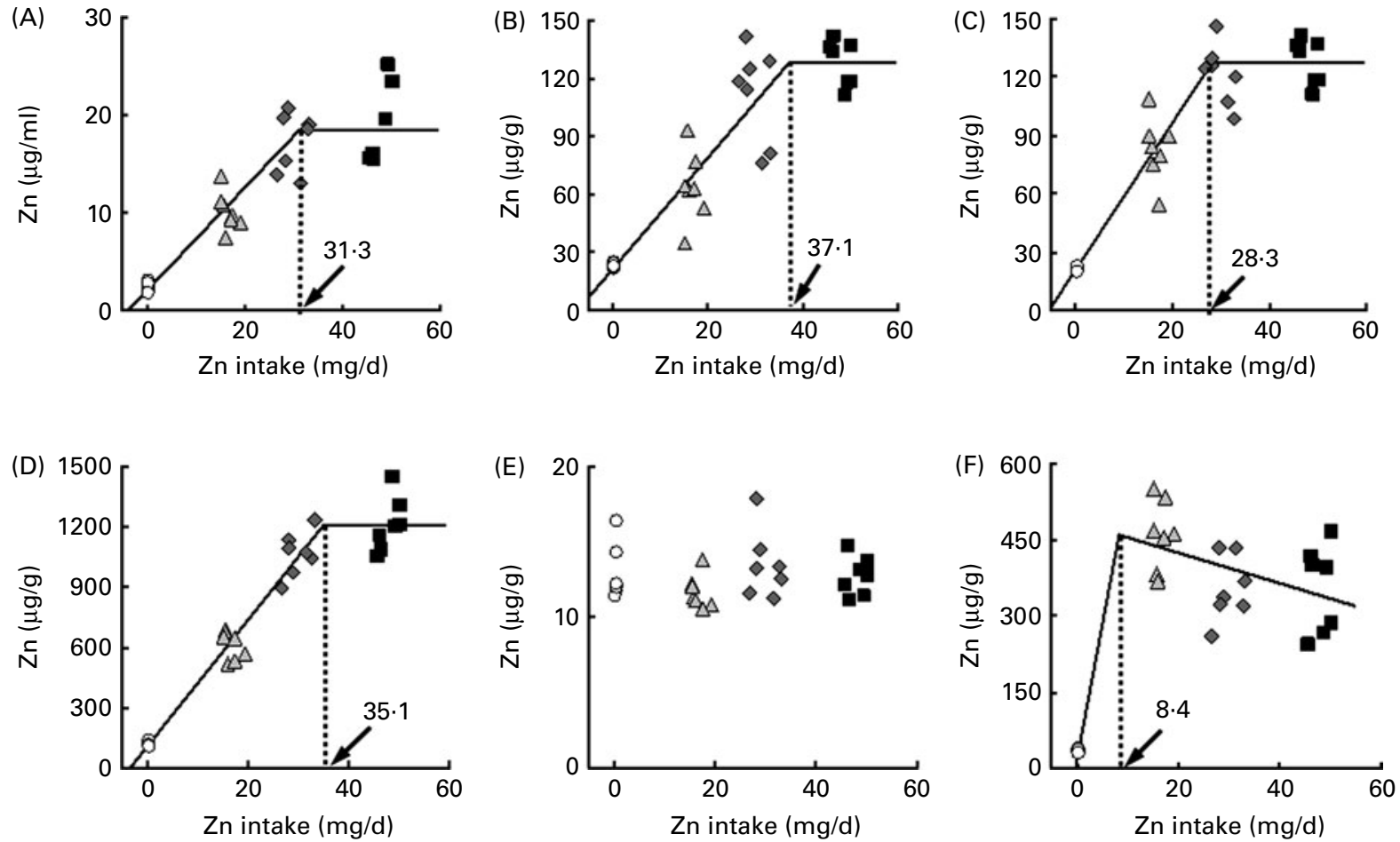

Fig. 4. Relationship between $\mathrm{Zn}$ intake and plasma and tissue concentrations of $\mathrm{Zn}$ in growing rats. Rats were fed diets with various concentrations of $\mathrm{Zn}$ for $10 \mathrm{~d}$. $\mathrm{Zn}$ concentrations in the (A) plasma, (B) liver, (C) kidney, (D) femur, (E) gastrocnemius muscle and (F) pancreas were plotted against average daily intake of Zn. The breaking point of daily $\mathrm{Zn}$ intake on plasma and tissue concentrations of $\mathrm{Zn}$ was calculated, and indicated in the figure by an arrow. $0,24 \mathrm{mg} Z \mathrm{n} / \mathrm{kg}$; $\Delta, 1016 \mathrm{mg} \mathrm{Zn} / \mathrm{kg} ; \diamond, 2008 \mathrm{mg} \mathrm{Zn} / \mathrm{kg} ; \quad 3000 \mathrm{mg} \mathrm{Zn} / \mathrm{kg}$. Note that there was no break point on $\mathrm{Zn}$ concentration in the gastrocnemius muscle.
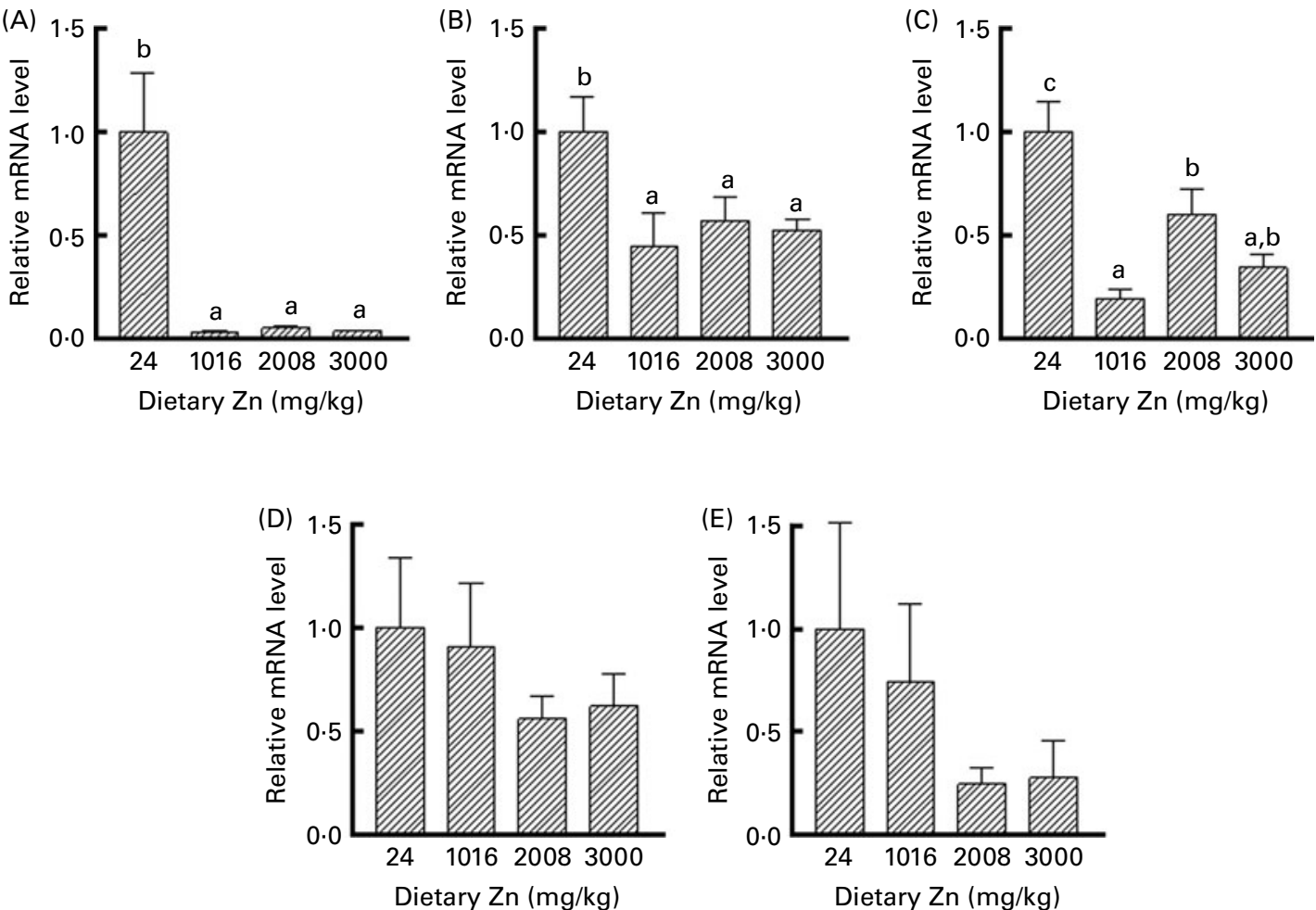

Fig. 5. Gene expression of $\mathrm{Zn}$ transporters in the small intestinal epithelium and the pancreas of rats. Rats were fed diets supplemented with various concentrations of Zn for $10 \mathrm{~d}$. Gene expression of (A) Zip4, (B) ZnT1 and (C) Zip5 in the small intestine, and (D) ZnT1 and (E) Zip5 in the pancreas was examined by quantitative RT-PCR. The transcription levels were expressed as ratios to hypoxanthine phosphoribosyltransferase 1 with the level in rats fed the basal diet set to 1. Values are means with their standard errors represented by vertical bars $(n 7){ }^{\mathrm{a}, \mathrm{b}, \mathrm{c}}$ Mean values with unlike letters were significantly different $(P<0.05)$. 

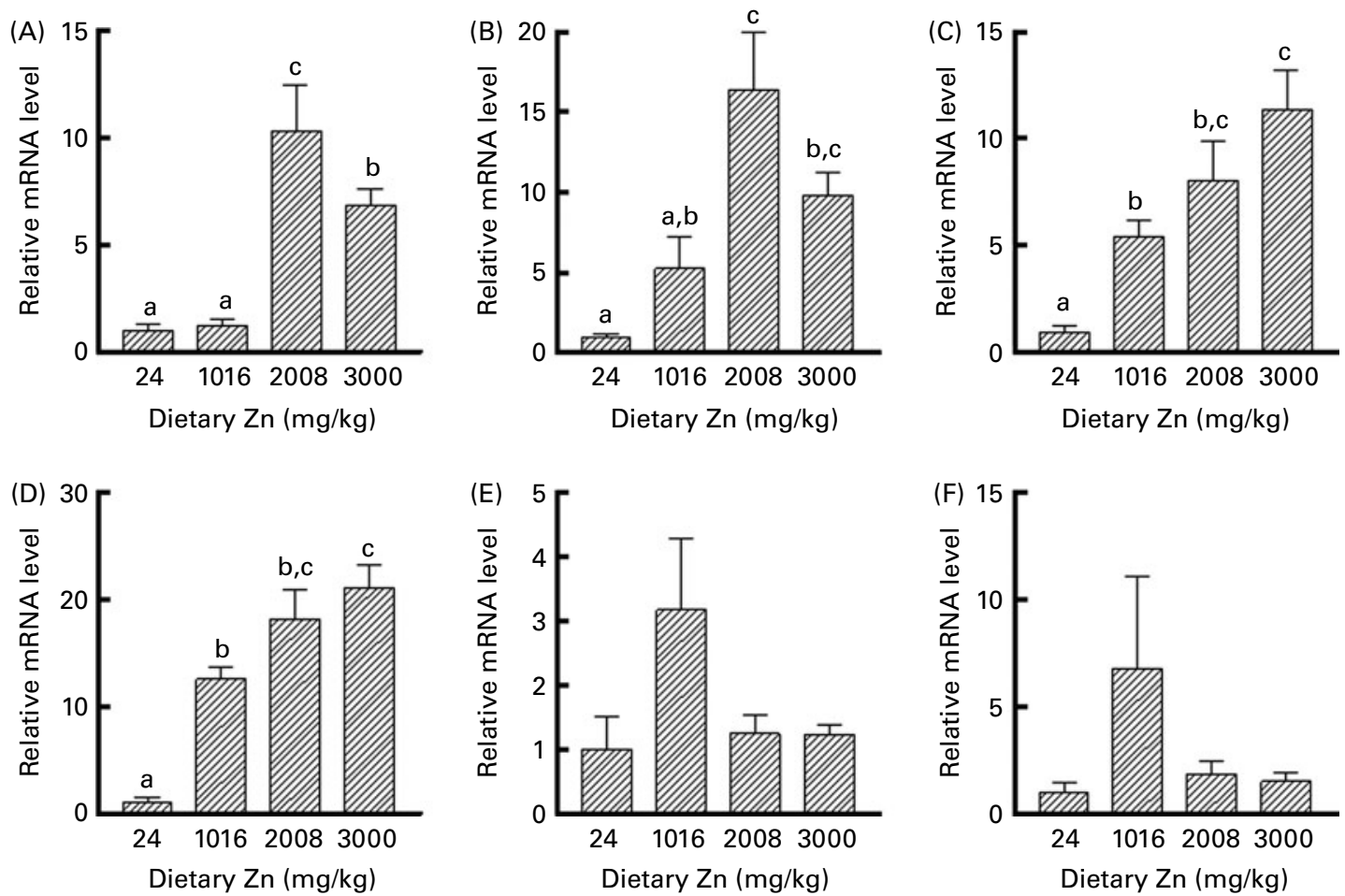

Fig. 6. Gene expression of metallothionein (Mt) in the small intestinal epithelium, liver and pancreas of rats. Rats were fed diets supplemented with various concentrations of $\mathrm{Zn}$ for $10 \mathrm{~d}$. Gene expression of (A, C, E) Mt-1a and (B, D, F) Mt-2a in the (A, B) small intestine, (C, D) liver and (E, F) pancreas was examined by quantitative RT-PCR. The transcription levels were expressed as ratios to hypoxanthine phosphoribosyltransferase 1 with the level in rats fed the basal diet set to 1 . Values are means with their standard errors represented by vertical bars $(n 7) .{ }^{a, b, c}$ Mean values with unlike letters were significantly different $(P<0 \cdot 05)$.

Mt is involved in Zn homeostasis, and Mt expression is induced by several metals including $\mathrm{Zn}^{(32,33)}$. Expression of $M t-1 a$ has been shown to change in parallel with that of $Z n T 1$ in response to Zn exposure in cultured hepatoma cells and fibroblasts ${ }^{(34)}$; we therefore evaluated $M t$ expression in the present study. The expression levels of $M t-1 a$ and $M t-2 a$ in the intestinal epithelium were higher in rats fed diets supplemented with 2008 or $3000 \mathrm{mg} \mathrm{Zn/kg}$ than in those fed the basal diet (Fig. 6(A) and (B)); Mt-1a expression was higher in rats fed a diet supplemented with $2008 \mathrm{mg} \mathrm{Zn} / \mathrm{kg}$ than in those fed a diet containing $3000 \mathrm{mg} \mathrm{Zn} / \mathrm{kg}$. The expression of $M t-1 a$ and $M t-2 a$ in the liver was higher in rats fed diets supplemented with $1016-3000 \mathrm{mg} \mathrm{Zn} / \mathrm{kg}$ than in those fed the basal diet; the expression increased in a dose-dependent manner (Fig. 6(C) and (D)). The regulatory expression of hepatic $M t-1 a$ and $M t-2 a$ in response to excess $\mathrm{Zn}$ intake is similar to the changes in $\mathrm{Zn}$ accumulation in the liver (Fig. 4(B)); this reflects the fact that Zn accumulated in the liver is incorporated into $\mathrm{Mt}-1 \mathrm{a}$ and $\mathrm{Mt}-2 \mathrm{a}$, which buffer excess $\mathrm{Zn}$ to provide protection from $\mathrm{Zn}$ toxicity $^{(33)}$. No significant changes in $M t$ expression were detected in the pancreas (Fig. 6(E) and (F)).

A previous study suggested that the increased expression of $I g f-1$ and its receptor are responsible for excess $\mathrm{Zn}$-induced growth promotion in piglets ${ }^{(13)}$. We evaluated expression of Igf- 1 in the intestinal epithelium and in the liver, one of the major Igf-1-producing organs ${ }^{(35)}$. Expression of $I g f-1$ was not significantly different among groups, irrespective of the tissues analysed (Fig. 7).

\section{Discussion}

The present study examined the short-term effects of extremely high $\mathrm{Zn}$ intake on body and tissue weight; tissue $\mathrm{Zn}$ concentration; and the expression of $\mathrm{Zn}$ transporters, Mt, and Igf-1 in growing rats. Our results revealed that, in contrast to studies in piglets, excess intake of $\mathrm{Zn}$ did not have any beneficial effects on growth, but rather induced a decrease in weight of the pancreas. The $\mathrm{NRC}^{(7)}$ proposed that excess $\mathrm{Zn}$ predominantly accumulates in organs such as the liver, kidney and bone in order to protect the pancreas, the organ most sensitive
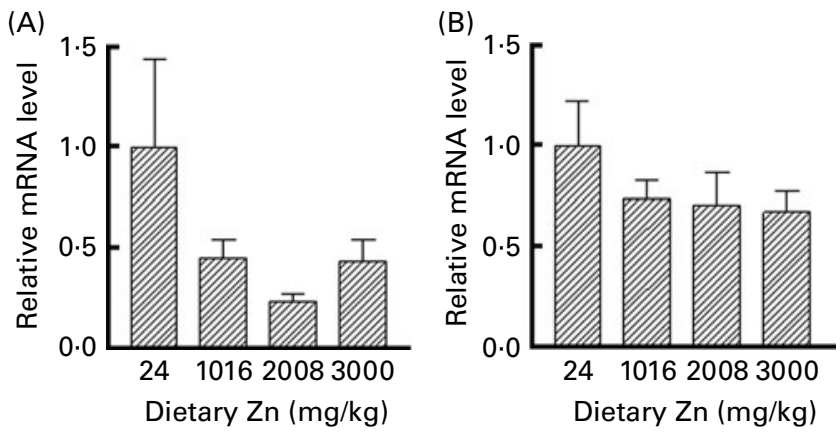

Fig. 7. Gene expression of insulin-like growth factor-1 (Igf-1) in the small intestinal epithelium and liver of rats. Rats were fed diets supplemented with various concentrations of $\mathrm{Zn}$ for $10 \mathrm{~d}$. Gene expression of $\lg f-1$ in the $(\mathrm{A})$ small intestine and (B) liver was examined by quantitative RT-PCR. The transcription levels were expressed as ratios to hypoxanthine phosphoribosyltransferase 1 with the level in rats fed the basal diet set to 1. Values are means with their standard errors represented by vertical bars $(n 7)$. 
to excess $\mathrm{Zn}$. The present results basically support this model: $\mathrm{Zn}$ concentrations in the liver, kidney and femur proportionally increased with increasing $\mathrm{Zn}$ intake up to $28-37 \mathrm{mg} / \mathrm{d}$. However, the weight of the pancreas was lower in rats that ingested more than $15 \mathrm{mg} / \mathrm{d} \mathrm{Zn}$. This indicates that the amount of $\mathrm{Zn}$ intake required to induce atrophy of the pancreas is smaller than that required to reach a plateau in $\mathrm{Zn}$ accumulation in other tissues. Thus, the present results obtained in rats ingesting extremely high concentrations of Zn for a short period suggest the imperfect buffering capacity of the liver, kidney and bone against excess $\mathrm{Zn}$ ingestion. Furthermore, our results suggest that $\mathrm{Zn}$ accumulation in the skeletal muscle, the tissue that stores the majority of $\mathrm{Zn}$ in the body, is not affected by dietary $Z n$ intake.

Zn depletion-induced $Z i p 4$ expression in the small intestine is well-characterised ${ }^{(36-38)}$. By contrast, less information is available regarding the expression of $\mathrm{Zn}$ transporters in animals fed excess Zn. Expression of $Z n T 1$ and $Z n T 2$ in the small intestine was significantly higher in rats fed a diet containing $180 \mathrm{mg} \mathrm{Zn/kg}$ for 2 weeks than in those fed a diet containing $30 \mathrm{mg} \mathrm{Zn} / \mathrm{kg}^{(39)}$. The present study indicates that excess $\mathrm{Zn}$ ingestion clearly down-regulates the mRNA expression of the $\mathrm{Zn}$ transporters involved in intestinal $\mathrm{Zn}$ absorption, Zip4 and ZnT1. The decrease in Zip4 expression was particularly evident; the gene transcript level of $Z i p 4$ in rats fed a diet supplemented with $1016 \mathrm{mg} \mathrm{Zn/kg} \mathrm{was} \mathrm{only}$ around $5 \%$ of that in rats fed the basal diet, whereas the ZnT1 mRNA level of rats fed a diet containing $1016 \mathrm{mg}$ $\mathrm{Zn} / \mathrm{kg}$ was around $35 \%$ of that in rats fed the basal diet. These results suggest that in addition to a system detecting $\mathrm{Zn}$ depletion, intestinal cells also have a system to sense excess $\mathrm{Zn}$, and they partly regulate $\mathrm{Zn}$ absorption through transcriptional inhibition of $\mathrm{Zn}$ transporters.

$Z n T 1, M t-1 a$ and $M t-2 a$ are transcriptionally regulated by metal-responsive transcription factor-1, a Zn-sensing transcription factor ${ }^{(40)}$, and the expression of both genes increases in response to $\mathrm{Zn}$ exposure in cultured cells ${ }^{(34,41,42)}$; however, excess $\mathrm{Zn}$ ingestion ( $>2008 \mathrm{mg} \mathrm{Zn} / \mathrm{kg}$ ) caused the downregulation of $Z n T 1$ mRNA expression in the intestinal epithelium but up-regulation of $M t-1 a$ and $M t-2 a$ mRNA expression. An unidentified additional regulatory mechanism of $Z n T 1$ expression is probably involved in rats fed a diet with extremely high $\mathrm{Zn}$ contents.

The capacity for $\mathrm{Zn}$ accumulation in the liver, kidney and bone in response to excess $\mathrm{Zn}$ ingestion was limited. Rats that ingested $28-37 \mathrm{mg} \mathrm{Zn} / \mathrm{d}$ could not accumulate additional $\mathrm{Zn}$ in these tissues; this $\mathrm{Zn}$ level corresponded to ingestion of a diet supplemented with $2008 \mathrm{mg} \mathrm{Zn/kg}$. These results suggest stimulation of $\mathrm{Zn}$ secretion by feeding diets containing more than $2008 \mathrm{mg} \mathrm{Zn/kg}$, or inhibition of $\mathrm{Zn}$ absorption, or both. Although Zip5 plays a role in $\mathrm{Zn}$ secretion across the intestinal mucosa ${ }^{(25)}$, the gene transcript level of $Z i p 5$ in the intestinal epithelium was not elevated but instead decreased in rats fed a diet supplemented with $1016 \mathrm{mg} \mathrm{Zn/kg} \mathrm{com-}$ pared to those fed the basal diet. Thus, it is unlikely that the Zip5-mediated $\mathrm{Zn}$ secretion is increased in rats fed diets with high $\mathrm{Zn}$ content. The pancreas is the major organ for endogenous $\mathrm{Zn}$ secretion into the gut ${ }^{(43)}$. Expression levels of pancreatic Zip5 and ZnT1, which are expressed predominantly in the acinar cells of the pancreas ${ }^{(25,26)}$, were not increased in response to the ingestion of diets supplemented with excess $\mathrm{Zn}$. These results suggest that the increased $\mathrm{Zn}$ secretion from the pancreas is not responsible for the limited Zn accumulation in the liver, kidney and bone.

Intestinal Mt levels are inversely related to the rate of $\mathrm{Zn}$ absorption $^{(44)}$, and it has been suggested that Mt inhibits $\mathrm{Zn}$ absorption ${ }^{(45)}$. Thus, the present finding that expression of $M t-1 a$ and $M t-2 a$ was up-regulated in the intestinal epithelium of rats fed diets supplemented with 2008 or $3000 \mathrm{mg} \mathrm{Zn/kg}$ may reflect an inhibition of intestinal $\mathrm{Zn}$ absorption in these rats. However, the expression of intestinal $M t-1 a$ and $M t-2 a$ was not significantly higher in rats fed the diet supplemented with $3000 \mathrm{mg} \mathrm{Zn/kg}$ than in those fed the diet containing $2008 \mathrm{mg} \mathrm{Zn} / \mathrm{kg}$. Thus, the limit of tissue $\mathrm{Zn}$ accumulation in rats fed the diet supplemented with $2008 \mathrm{mg} \mathrm{Zn/kg}$ could not be explained by the Mt-induced inhibition of $\mathrm{Zn}$ absorption. Although gene transcript levels of intestinal Zip4 were not further decreased in rats fed diets containing more than $1016 \mathrm{mg} \mathrm{Zn} / \mathrm{kg}$ in this study, processing and translocation of Zip4 are modified in response to changes in $\mathrm{Zn}$ status ${ }^{(46,47)}$ Thus, post-translational modifications may be responsible for the defence against $\mathrm{Zn}$ ingestion in diets containing more than $2008 \mathrm{mg} \mathrm{Zn/kg}$.

In piglets, short-term feeding of a diet supplemented with $3000 \mathrm{mg} \mathrm{Zn/kg}$ effectively enhanced BW gain ${ }^{(11-13)}$, and this feeding regimen is applied in practice on pig farms. $\mathrm{Li}$ et $a{ }^{(13)}$ suggested that the excess $\mathrm{Zn}$ ingestion stimulates Igf-1-mediated signalling, which enhances the villous height of the small intestinal mucosa resulting in growth promotion of piglets. Considering that $I g f-1$ expression in the small intestine and in the liver was not significantly increased in response to excess $\mathrm{Zn}$ ingestion, the inability to stimulate the Igf- 1 axis may be one of the reasons why body growth was not accelerated in rats fed a diet supplemented with $3000 \mathrm{mg} \mathrm{Zn/kg}$.

The present study clarified that growing rats have defence mechanisms against excess $\mathrm{Zn}$ ingestion; in addition to the effective accumulation of excess $\mathrm{Zn}$ in the liver, kidney and bone, the down-regulated mRNA expression of $\mathrm{Zn}$ transporters involved in intestinal absorption contributes to the protection of the pancreas against excess $\mathrm{Zn}$-mediated adverse effects. Furthermore, up-regulation of Mt expression in the small intestine results in the inhibition of $\mathrm{Zn}$ absorption. These multiple defences may contribute to the relative tolerance to excess $\mathrm{Zn}$ ingestion.

\section{Acknowledgements}

The present study received no specific grant from any funding agency in the public, commercial or not-for-profit sectors. T. F., T. M. and M. F. designed the experiments; T. F. performed the experiments; T. F., T. M. and M. F. analysed the data and wrote the paper. All authors discussed the results and approved the manuscript in its final version. The authors declare no conflict of interest. 


\section{References}

1. McCall KA, Huang C \& Fierke CA (2000) Function and mechanism of zinc metalloenzymes. J Nutr 130, 1437S-1446S.

2. Giugliano R \& Millward DJ (1984) Growth and zinc homeostasis in the severely Zn-deficient rat. Br J Nutr 52, 545-560.

3. Park JH, Grandjean CJ, Hart MH, et al. (1986) Effect of pure zinc deficiency on glucose tolerance and insulin and glucagon levels. Am J Physiol 251, E273-E278.

4. Fairweather-Tait S \& Hurrell RF (1996) Bioavailability of minerals and trace elements. Nutr Res Rev 9, 295-324.

5. Sandstead HH, Frederickson CJ \& Penland JG (2000) History of zinc as related to brain function. J Nutr 130, 496S-502S.

6. Sutomo FX, Woutersen RA \& Van den Hamer CJ (1992) Effects of elevated zinc intake on the copper metabolism and the pancreas of the mouse. $J$ Trace Elem Electrolytes Health Dis 6, 75-80.

7. National Research Council (2005) Mineral Tolerance of Animals, 2nd ed. Washington, DC: National Academic Press.

8. Jenkins KJ \& Hidiroglou M (1991) Tolerance of the preruminant calf for excess manganese or zinc in milk replacer. J Dairy Sci 74, 1047-1053.

9. Henry PR, Littell RC \& Ammerman CB (1997) Effect of high dietary zinc concentration and length of zinc feeding on feed intake and tissue zinc concentration in sheep. Anim Feed Sci Technol 66, 237-245.

10. Ansari MS, Miller WJ, Neathery MW, et al. (1976) Zinc metabolism and homeostasis in rats fed a wide range of high dietary zinc levels. Proc Soc Exp Biol Med 152, 192-194.

11. Hill GM, Mahan DC, Carter SD, et al. (2001) NCR-42 Committee on Swine Nutrition. Effect of pharmacological concentrations of zinc oxide with or without the inclusion of an antibacterial agent on nursery pig performance. J Anim Sci 79, 934-941.

12. Mavromichalis I, Peter CM, Parr TM, et al. (2000) Growthpromoting efficacy in young pigs of two sources of zinc oxide having either a high or a low bioavailability of zinc. J Anim Sci 78, 2896-2902.

13. Li X, Yin J, Li D, et al. (2006) Dietary supplementation with zinc oxide increases Igf-I and Igf-I receptor gene expression in the small intestine of weanling piglets. J Nutr 136, $1786-1791$.

14. National Research Council (1998) Nutrient Requirements of Swine, 10th ed. Washington, DC: National Academic Press.

15. Hill GM, Mahan DC, Carter SD, et al. (2001) Effect of pharmacological concentrations of zinc oxide with or without the inclusion of an antibacterial agent on nursery pig performance. J Anim Sci 79, 934-941.

16. Poulsen HD (1995) Zinc oxide for weaning piglets. Acta Agric Scand A Anim Sci 45, 159-167.

17. Jensen-Waern M, Melin L, Lindberg R, et al. (1998) Dietary zinc oxide in weaned pigs - effects on performance, tissue concentrations, morphology, neutrophil functions and faecal microflora. Res Vet Sci 64, 225-231.

18. Katouli M, Melin L, Jensen-Waern M, et al. (1999) The effect of zinc oxide supplementation on the stability of the intestinal flora with special reference to composition of coliforms in weaned pigs. $J$ Appl Microbiol 87, 564-573.

19. Guerinot ML (2000) The ZIP family of metal transporters. Biochim Biophys Acta 1465, 190-198.

20. Taylor KM \& Nicholson RI (2003) The LZT proteins; the LIV-1 subfamily of zinc transporters. Biochim Biophys Acta 1611, 16-30.

21. Kambe T, Yamaguchi-Iwai Y, Sasaki R, et al. (2004) Overview of mammalian zinc transporters. Cell Mol Life Sci $\mathbf{6 1}$, 49-68.
22. Palmiter RD \& Huang L (2004) Efflux and compartmentalization of zinc by members of the SLC30 family of solute carriers. Pflugers Arch 447, 744-751.

23. McMahon RJ \& Cousins RJ (1998) Regulation of the zinc transporter ZnT-1 by dietary zinc. Proc Natl Acad Sci U S A 95, 4841-4846.

24. Wang K, Zhou B, Kuo YM, et al. (2002) A novel member of a zinc transporter family is defective in acrodermatitis enteropathica. Am J Hum Genet 71, 66-73.

25. Dufner-Beattie J, Kuo YM, Gitschier J, et al. (2004) The adaptive response to dietary zinc in mice involves the differential cellular localization and zinc regulation of the zinc transporters ZIP4 and ZIP5. J Biol Chem 279, 49082-49090.

26. Liuzzi JP, Bobo JA, Lichten LA, et al. (2004) Responsive transporter genes within the murine intestinal-pancreatic axis form a basis of zinc homeostasis. Proc Natl Acad Sci U S A 101, 14355-14360.

27. National Research Council (1995) Nutrient Requirements of Laboratory Animals, 4th ed. Washington, DC: National Academic Press.

28. Reeves PG (1997) Components of the AIN-93 diets as improvements in the AIN-76A diet. J Nutr 127, 838S-841S.

29. SAS Institute (2001) SAS User's Guide: Statistics (Ver. 9.2). Cary, NC: SAS Institute.

30. Fosmire GJ (1990) Zinc toxicity. Am J Clin Nutr 51, 225-227.

31. Jackson MJ (1989) Physiology of zinc: general aspects. In Zinc in Human Biology, pp. 1-14 [CF Mills, editor]. Berlin: Springer-Verlag.

32. Palmiter RD (1994) Regulation of metallothionein genes by heavy metals appears to be mediated by a zinc-sensitive inhibitor that interacts with a constitutively active transcription factor, MTF-1. Proc Natl Acad Sci U S A 91, 1219-1223.

33. Mocchegiani E, Malavolta M, Costarelli L, et al. (2010) Zinc, metallothioneins and immunosenescence. Proc Nutr Soc 69, 290-299.

34. Langmade SJ, Ravindra R, Daniels PJ, et al. (2000) The transcription factor MTF-1 mediates metal regulation of the mouse ZnT1 gene. J Biol Chem 275, 34803-34809.

35. Ohlsson C, Mohan S, Sjögren K, et al. (2009) The role of liver-derived insulin-like growth factor-I. Endocr Rev 30, $494-535$.

36. Dufner-Beattie J, Wang F, Kuo YM, et al. (2003) The acrodermatitis enteropathica gene ZIP4 encodes a tissue-specific, zinc-regulated zinc transporter in mice. $J$ Biol Chem 278, $33474-33481$

37. Weaver BP, Dufner-Beattie J, Kambe T, et al. (2007) Novel zinc-responsive post-transcriptional mechanisms reciprocally regulate expression of the mouse Slc39a4 and Slc39a5 zinc transporters (Zip4 and Zip5). Biol Chem 388, 1301-1312.

38. Jou MY, Hall AG, Philipps AF, et al. (2009) Tissue-specific alterations in zinc transporter expression in intestine and liver reflect a threshold for homeostatic compensation during dietary zinc deficiency in weanling rats. J Nutr 139, 835-841.

39. Liuzzi JP, Blanchard RK \& Cousins RJ (2001) Differential regulation of zinc transporter 1,2, and 4 mRNA expression by dietary zinc in rats. $J$ Nutr 131, 46-52.

40. Laity JH \& Andrews GK (2007) Understanding the mechanisms of zinc-sensing by metal-response element binding transcription factor-1 (MTF-1). Arch Biochem Biophys 463, 201-210.

41. Yang M, Kroft SH \& Chitambar CR (2007) Gene expression analysis of gallium-resistant and gallium-sensitive lymphoma cells reveals a role for metal-responsive transcription factor-1, metallothionein-2A, and zinc transporter- 1 in modulating the 
antineoplastic activity of gallium nitrate. Mol Cancer Ther $\mathbf{6}$, 633-643.

42. Jackson KA, Valentine RA, McKay JA, et al. (2009) Analysis of differential gene-regulatory responses to zinc in human intestinal and placental cell lines. Br J Nutr 101, 1474-1483.

43. McClain CJ (1990) The pancreas and zinc homeostasis. J Lab Clin Med 116, 275-276.

44. Hoadley JE, Leinart AS \& Cousins RJ (1988) Relationship of $65 \mathrm{Zn}$ absorption kinetics to intestinal metallothionein in rats: effects of zinc depletion and fasting. $J$ Nutr 118, 497-502.
45. Davis SR, McMahon RJ \& Cousins RJ (1998) Metallothionein knockout and transgenic mice exhibit altered intestinal processing of zinc with uniform zinc-dependent zinc transporter-1 expression. J Nutr 128, 825-831.

46. Kim BE, Wang F, Dufner-Beattie J, et al. (2004) Zn2 + -stimulated endocytosis of the MZIP4 zinc transporter regulates its location at the plasma membrane.J Biol Chem 279, 4523-4530.

47. Kambe T \& Andrews GK (2009) Novel proteolytic processing of the ectodomain of the zinc transporter ZIP4 (SLC39A4) during zinc deficiency is inhibited by acrodermatitis enteropathica mutations. Mol Cell Biol 29, 129-139. 